\title{
Historical Topography and British History in Camden's Britannia
}

\section{WILLIAM ROCKETT}

B ritain acquired a national history only after its coherence as a territorial entity had been established, and these two components of the national identity - territorial and historical definition - were products of the Tudor era. Cromwell reordered England's constitution by cutting off Rome's entitlement to English taxes and then building a program of reform on the related concepts of national sovereignty and the imperial status of the Crown. ${ }^{1}$ These were enacted by means of statute. Statute was also a device for achieving territorial unification. There was first an act for abolishing the franchisal rights of local landlords and enforcing the royal authority in all parts of the realm. This legislation was known as the Act for Recontinuing certain Liberties and Franchises heretofore taken from the Crown. ${ }^{2}$ It was composed by Cromwell, and it legally terminated the feudal era in Britain by placing jurisdictional uniformity over the prerogatives of strong men in the provinces. It set out the territorial extension of the Crown's powers. An act for anglicizing the principality and marches of Wales came next. This was the so-called Act of Union of $1536 .^{3}$ It annexed the marcher lordships to existing counties and created five new ones (Monmouth, Brecknock, Radnor, Montgomery, and Denbigh), and it enforced English legal and tenurial customs in these newborn members of the king's dominion.

For three months beginning on the first of October in 1536 the rebellion known as the Pilgrimage of Grace threatened to reverse the movement of reform. Its leaders, who were demanding an end to the dissolution of the monasteries, were persuaded by the duke of Norfolk to disband on the sixth of December. ${ }^{4}$ However, when rioting continued into January and February of the new year, Norfolk resorted to martial law and executions to teach the lesson of Henry's supremacy in the north. On the sixth.of June, 1537, Cromwell wrote that the whole realm was at peace, and the Council in the North was set up to govern Cumberland, Westmorland, and Northumberland. ${ }^{5}$ 
The conciliar and jurisdictional ties uniting the realm and linking it to Westminster formed a new territorial coherence, and the immense and intricately heterogeneous topography of the British countryside became a geopolitical unity. The customary social spheres formed in the era of the Heptarchy, including those of the Welsh and northern borders, became one polity, if not in every respect one society, through the territorial consolidation carried out in the name of national sovereignty.

National sovereignty, then, altered the shape of British history. An entire new enterprise of scholarship was required to define the historical parameters of the new order, and the provinces as well as Britain's topographical character were discovered in the endeavor of seeking and explaining the ancient origins of the nation's institutions. ${ }^{6}$ John Leland was the first to imagine a national history written from the point of view of provincial localities. He received a commission in 1533 to tour the monasteries and inventory their library holdings and in 1536 embarked upon a national perambulation in the hope of composing a comprehensive historical and topographical portrait. ${ }^{7}$ He was prevented by illness from completing it, but in 1546 he sketched a draft of his design in a New Year's letter to the king. What he proposed was a comprehensive national profile. Its separate parts were to include histories of the aristocracy and the kings of England, biographies of English authors, descriptions of the adjacent islands, and a work of historical topography in as many books as there were counties in England and Wales. In this last part of his projected work Leland intended to describe the origins and history of the chief towns and castles of the realm. If it had been completed it would have resembled Biondo's Italia illustrata as well as Camden's Britannia. It would have been a book of local histories organized on some sort of topographical plan, perhaps an itinerary, illustrating the geographical dimensions of the newly consolidated realm. Leland was trying to write a kind of history that would be national in a territorial as well as a political sense. In six years of touring he had found, in his words, "a hole worlde of thinges very memorable" and was seeking to compose a work of British history by forming a narrative that would correspond in some way to the course of his itineraries and mirror the provincial dimensions of the national idea. The design of this part of his project would have been cartographic (that is, its form would have been topographical rather than chronological), and its substance would have been a compendium of local chronicle materials. Leland was endeavoring to embrace the whole conception of the Tudor polity, mirroring in maps and narrative description its shape and dimension as well as its 
history, and he meant to offer it to the king to honor the recovery of his nation's sovereignty from Roman usurpation.

In the historiography to which he was adhering, the scope of national sovereignty and the jurisdictional sweep of the Crown determined the nation's territorial dimensions. These, in turn, shaped Leland's conception of the national past in the sense that his understanding of Britain's history was formed and imbued by the perception of territorial integrity to which he was awakened in his journeys. By conducting a national perambulation Leland found a way of recreating British history, endowing the customary social orders of the provinces with a kind of historical enfranchisement by bringing them within the sphere of nationhood. He inspired a generation of journeying scholars who then sought to illuminate the provincial origins of the nation's institutions, most notably the Kentish and Cheshire historians William Lambarde and William Smith, in addition to William Camden, John Norden, and John Speed. The comprehensive surveys which they composed - an unfinished topographical dictionary by Lambarde which was not published until 1730, Camden's Britannia, Smith's Particular Description of England, Norden's unfinished Speculum Britanniae, and Speed's Theatre of the Empire of Great Britain - are collections of local histories employing topographical modes of organization. They mirror the nationalist spirit of the Renaissance and the new humanist scholarship as well - particularly diplomatics - and the words speculum and theatre in the titles of works by Norden and Speed mark their indebtedness to Renaissance geography, particularly to the works of de Jode and Ortelius. It was Ortelius who visited England in 1577 and proposed to Camden the idea of restoring Britain's antiquity. ${ }^{8}$

Camden toured the British provinces for four years beginning in 1571 and after that whenever his duties at Westminster School would permit. His journeys were exploratory and archaeological. He recorded observations of natural and geographical interest, and he had a good eye for Plinyesque curiosities. However, his principal aim was to make a topographical survey and identify the contours of Britain's political geography because in framing the narrative of Britannia he sought to devise a way of mirroring Britain's national origins. In the first edition of 1586 he recreated his perambulation into a sequence of tours of all the counties, beginning in the West with Cornwall and Devonshire and then moving north, and by doing so the found a way of imposing shape and symmetry upon his immense collection of documentary and archaeological materials as well as describing the coherent form of the national past. He composed a topography rather than a calendar or chronicle of British society, reconstructing from local 
materials the decisive events in the nation's past and the evolutionary formation of a national identity.

Exactly where Camden's journeys led in the four years after he left Oxford it will never be possible to say, nor is it certain that during these years a plan for a comprehensive description was taking shape. It is certain, however, that his projected work, when he was able to form a design for it, would be a chorographical study having to do with the places of British antiquity, and he no doubt decided early that one of his first tasks would be to delineate the shape of the Roman hegemony in Britain. He decidedly would not follow the linear, replicative mode of chronicle narrative but would fashion a topographical framework so that he would be able to compose a national history by forming a collection of local historical and descriptive profiles.

He added to his store of documentary materials by examining the physical remains of the Saxon, Danish, and Norman as well as the Roman era and recording his observations of coins, inscriptions, and works of monumental art in church and countryside. By examining the relics of the remote past he hoped to make a coherent narrative of the incomplete and often cryptic remarks concerning Britain which he found in the works of Caesar, Tacitus, Strabo, Diodorus Siculus, and Polybius. ${ }^{9}$ This part of Camden's research was archacological. Another of its dimensions was toponymical. He understood that there could be no way of describing Britain's origins without recovering the ancient Celtic and Roman equivalents of the English names with which they had been replaced and which, then, were obscuring the early history of important provincial sites. ${ }^{10}$ He cited Plato's discussion, in the Cratylus, of primitive names used by barbarous peoples in order to illustrate the importance of recovering the names used by the Britons in the era of the Roman occupation. Their place-names had the status of antiquity, and so in Camden's humanistic view they possessed a unique sort of importance: they represented the carliest traces of British civilization. Camden thereforc taught himself sixteenth century Welsh as well as Old English in order to enable himself to unlock the information stored in the earliest British place-names. His toponymical texts were the Pcutinger Tables, Ptolemy's Geography, the Notitia occidentalis imperii, and the British section of the Antoninc Itinerary, which was not a painted itinerary like the Peutinger Tables but a list of important stations throughout the Empire at the time of the Antonine empcrors. ${ }^{11}$ This last seems to have been of greater use than the others. Camden cites it more often than he does the others and seems to have regarded it as a comprehensive and coherent topographical guide. 
The Antonine Itinerary had two parts, one for land and one for water routes, and thus two names: Itinerarium provinciarum Antonini Augusti and Imperatoris Antonini Augusti itinerarium maritimum. It supposedly was planned for the emperor Caracalla, who made a journey from Rome to Egypt early in the third century, and it then underwent a number of revisions before reaching its final state in 290 B.C. ${ }^{12}$ Caracalla attended Severus during a British campaign early in the third century and later presided over the abandonment of the Roman garrisons in Scotland in order to strengthen the Hadrianic frontier. ${ }^{13}$

In the British section of the Antonine Itinerary there were one hundred forty-five stations divided among fifteen separate tours. ${ }^{14}$ Only one of these, the second, ran the length of Roman Britain from a point fourteen miles north of Hadrian's Wall to Richborough in Kent. There were others running from London to northern points and to points in Kent and in East Anglia. There was a northern tour following a course from Hadrian's Wall to Patrington on the Yorkshire side of Humber, and five tours in Wales and the Marches. Exeter was the westernmost point, and Hadrian's Wall was the northern limit because the Romans had withdrawn from the Antonine Wall more than half a century before the Antonine Itinerary was completed.

Camden used the Antonine Itinerary to correlate ancient and contemporary sites and to identify ruins whose names had been obliterated. He composed etymologies of Celtic place names in his discussion of Maldon, Brettenham, New Sarum, Gormonchester, Carlisle, and Manchester, and he identified the Celtic equivalents of Tadcaster, Werminster, Brancaster, Leiton (a place Camden identifies as a village five miles distant from London), and a village in Cumberland whose inhabitants called it Old Carlisle. He identified the remotest northern point of the Empire where the Antonine Itinerary commenced (Blatobulgium on the Hadrianic wall, near present Burgh by Sands, Cumberland), and he fixed the site of Clausentum northeast of Southampton between Regnum on one side and Venta on the other. He identified Agelocum (Littleborough, Nottinghamshire) and Etocetum (Uttoxeter, Staffordshire) by estimating distances from their ruins to other places in the Antonine Itinerary, and he identified the village of Broughton on the River Test in Hampshire as Brage, which was sited ir: the Antonine Itinerary at a point nine miles from Sorbiodunum (Old Sarum). He identified the chief cities of the Attrebatii, the Regni, the Iceni, and the Cornavii. He includes a digression on Roman municipia in his discussion of Verolamium and remarks on coloniae in his discussions of Eboracum (York) and Camolodunum (Maldon). He believed that Uriconium (Wroxeter) and Brannogenium (Worcester) were used by the 
Romans to curb the Britons who lived beyond the Severn and that Deva (Chester), where the twentieth legion under Agricola was seated, was a barrier against the Ordovices.

The Roman forces in the north were garrisoned at Virosidum (present Warwick, Cumberland), where the sixth cohort of the Nervii were stationed, at Olenacum (present Linstock, Cumberland), and at Aesica (Netherby upon Esk in Cumberland). The first cohort of the Tungri were garrisoned at Bremeturacum (Ribchester in Lancashire), and the first wing of the Astures at Condercum (Chester le Street in the Bishopric of Durham). Gabrosentum (Gateshead in the Bishopric of Durham) was defended by the second cohort of the Thracians.

What this illustrates is that Camden was seeking to restore Britain's antiquity but not exactly in the sense historians ordinarily have supposed. He was seeking to explain the origins of the British polity to a cultivated European audience with a serious scholarly interest in antiquity. In attempting to explain how his nation was formed, he quite naturally began by establishing the contours of Britain's Roman era. In this preliminary part of his design the Antonine Itinerary was one of several evidentiary sources. Unlike the others, however, it had both completeness and unity. It was geographically more comprehensive than the others, including the British section of Ptolemy's Geography, and so Camden used it more methodically and more consistently than the others. It served as a topographical guide to ancient provincial sites and contained the shadowiest intimations having to do with Britain's ancient peoples, the Celtic tribes inhabiting the island when the Romans arrived.

Britannia has three parts. It opens with a chronological survey of Britain's main historical divisions - British, Roman, Saxon, Danish, and Norman and closes with descriptive surveys of Scotland and Ireland. The opening section contains essays on the courts and the aristocracy, and the closing section is a guide to the principal cities of the Scottish and Irish provinces. The well-known county tours make up the central section. In these Camden journeys from town to town following courses determined by the topographical contours of the counties, seeking out the remains of antiquity, and recreating from chronicles and other documents and artifacts the descent of hamlets, towns, walls, gates, bridges, manors, churches, castles, parishes, and bishops' sees. He organizes these into a sequence of county itineraries and succeeds, as Leland had been prevented from doing, in illuminating the provincial and territorial constituents of the national idea. He projected a conception of Britain's past onto the narrative equivalent 
of a plane surface and made one national fabric of many provincial components.

The principal feature of its organizational plan is a structure of seventeen parts corresponding to the seventeen territorial divisions of the ancient Britons. Within these divisions Camden arranged his fifty-two county itineraries. The structural framework of Britannia therefore conforms to the political geography of ancient Britain and mirrors the earliest British polity. In itself, the narrative framework of Britannia is a part of Camden's cultural statement. The classical authors (principally Tacitus, Ptolemy, and Strabo) were Camden's sources for the ancient Britons - for etymologies of their tribal names, their continental migrations, and the parts of Britain they inhabited - and from their works Camden devised the headings of each of his provincial divisions. The territories of the people known in his sources as the Danmonii form the opening section, the tours of Cornwall and Devonshire, and from here he proceeds to the parts inhabited by the Durotriges (Dorsetshire), the Belgae (Somersetshire, Wiltshire, and Hampshire), the Attrebatii (Berkshire), the Regni (Surrey and Sussex), the Dobuni (Gloucestershire and Oxfordshire), the Trinobantes (Middlesex and Essex), and so through the regions of East Anglia, the Midlands, and the North. The twelve Welsh counties are arranged within the tribal divisions of the Silures, the Dimetae, and the Ordovices, and Britannia closes, then, with tours of the regions inhabited by the Brigantes and the Ottadini (Yorkshire, Richmondshire, Lancashire, the Bishopric of Durham, Westmorland, Cumberland, and Northumberland).

In fashioning a framework of ancient territorial divisions for his county profiles Camden was following the procedure of Biondo's Italia illustrata, which is also a national itinerary organized along topographical lines and divided into ancient provinces. ${ }^{15}$ Biondo planned his other descriptive work, Roma ristaurata of about 1446, as a survey of Rome's architectural monuments, taking up in order gates, baths, temples, theaters, and fora. However, in Italia illustrata (c. 1453), the first national chorography of the Renaissance, he began in the north and followed a course leading to the south, visiting the monuments and ruins of the Venetian and Istrian regions and those of Lombardy, Umbria, and Picenum before arriving at last in Campania and Apulia. Italia illustrata, like Britannia, contains place-name etymologies and notes on important authors and scholars as well as histories of the fountains, gates, and bridges in the citics and towns of the eighteen regions of pre-Augustan Italy. It was Biondo's aim to portray the national integrity of the peoples inhabiting the peninsula first by composing in the Decades, which was completed in about 1460 , a unified conception 
of Italian history from the fall of Rome to the middle of the fifteenth century and then in Italia illustrata to represent Italy's territorial wholeness by conducting a survey in the form of a national itinerary. Camden's provincial tours, taken altogether, represent the national integrity of the British peoples by portraying the continuity of their history, and his itinerary format illuminates the territorial aspect of this British solidarity by tracing the dimensions of the regions they inhabited. Biondo and Camden both were of the scientific rather than the rhetorical school of authorship, and by composing their national topographies on frameworks of ancient territorial divisions they illustrated the potential for national definition which lay in the humanist concept of antiquity. ${ }^{16}$

With the exception of Sir Thomas Kendrick, who viewed Britannia as a work of antiquarian scholarship, and Richard Helgerson, who viewed it as subversive, no student of Camden of whom I know has failed to argue that its central and principal focus is Roman Britain. ${ }^{17}$ Sir Maurice Powicke believed it to be a commentary on the Antonine Itinerary, and R. J. Dunn viewed it as a study of British antiquity. ${ }^{18} \mathrm{~F}$. J. Levy felt that its purpose was to elucidate Roman names in Britain, and Stuart Piggott remarked that its initial purpose was to elucidate the ancient British topography in order to enable Britain "to take her rightful place at once within the world of antiquity and that of international scholarship." ${ }^{.19}$ Graham Parry recently has written that Camden relegated primitive Britain to "barbarian status" and that his purpose in Britannia was to portray Britain as "formed and stamped by Roman greatness." 20

I would like to broaden the scope of this discussion by proposing that the chorographical works of the English Renaissance were a product of the nation-forming movement of the 1530's and that they were the discursive equivalent of the mapping enterprise. The creation of national sovereignty as well as constitutional and territorial unity in the era of Henry's quarrel with Rome altered the complexion of British scholarship, as the endeavors of Leland, Bale, and Talbot illustrate, as well as those of the scholars assembled in Cromwell's household (Starkey, Morison, Taverner, and Marshall), whose purposes were more narrowly polemical. The nationalist clement already present in British historiography was heightened, and a new interest in the conjunction of history and cartography was engendered, causing Saxton and the other Elizabethan surveyors and cartographers, as well as Camden, to embark upon national itinerarics. As a humanist who was inspired by the idea of his nation's historical continuity, Camden followed a strategy which others had employed: he fashioned from classical historical and geographical materials a concept of antiquity and with this 
he identified his nation's origins, endowing Britain with historical inevitability by identifying the chronological point of its birth or inception.

\section{University of Oregon}

\section{Notes}

1 For the formation of the Tudor polity in the Cromwellian era, see G. R. Elton, England under the Tudors, 2nd ed. (London: Methuen, 1974), 130-7, and Reform and Reformation: England, 1509-1558 (Cambridge, Mass.: Harvard University Press, 1977), pp. 174-229.

2 G. R. Elton, ed., The. Tudor Constitution: Documents and Commentary (Cambridge: Cambridge University Press, 1960), pp. 37-9.

3 C. H. Williams, ed., English Historical Documents, 1485-1558 (New York: Oxford University Press, 1967), pp. 554-62.

4 For a concise discussion of Norfolk's role in the suppression of the Pilgrimage of Grace see Mervyn James, Society, Politics, and Culture (Cambridge: Cambridge University Press, 1986), pp. 352-3. See also Elton, Reform, pp. 260-71, and Scott Michael Harrison, The Pilgrimage of Grace in the Lake Counties, 1536-7 (London: Royal Historical Society, 1981), pp. 87-137.

5 Calendar of Letters and Papers Foreign and Domestic, pp. 12, 14.

6 For the impact of the Cromwellian revolution upon Tudor scholarship, see Elton, Reform and Renewal: Thomas Cromwell and the Common Weal (Cambridge: Cambridge University Press, 1973), pp. 3-65, David S. Berkowitz, Humanist Scholarship and Public Order: Two Tracts against the Pilgrimage of Grace by Sir Richard Morison (Washington: Folger Books, 1984), pp. 19-69, and May McKisack, Medieval History in the Tudor Age (Oxford: Clarendon, 1971), pp. 1-25.

7 See L. Toulmin Smith, The Itinerary of John Leland in or about the years 1535-1543, 5 vols. (London: Centaur Press, 1964), I: viii-xiv.

8 Sir Maurice Powicke discusses Camden's visit with Ortelius in "William Camden," Essays and Studies, n.s., 1 (1948), 74.

9 The point concerning Camden's use of classical sources was first made by Thomas Smith in his Latin life of Camden, which was translated into English by Bishop Gibson in his 1695 edition of Britannia. See also Stuart Piggott, "William Camden and the Britannia," Proceedings of the British Academy 37 (1951), pp. 206-7.

10 See "The Life of Mr. Camden" in Britannia, tr. Bishop Edmund Gibson (London, 1695), n.p.

11 For discussions of ancient topographical guides, including those used by Camden, see O. A. W. Dilke, "Itineraries and Geographical Maps in the early and late Roman Empire," in Cartography in Prehistoric, Ancient, and Medieval Europe and the Mediterranean, ed. Harley, J.B., and David Woodward (Chicago: University of Chicago Press, 1987), pp. 235-6.

12 Dilke, p. 235.

13 Peter Salway, Roman Britain (Oxford: Clarendon, 1981), pp. 228 and 242-4.

14 For a list of the British stations and a discussion of the British section of the Antonine Itinerary, see O. A. W. Dilke, Greek and Roman Maps (Ithaca: Cornell University Press, 1985), pp. 126-7. 
15 For an illuminating recent discussion of Biondo's Italia illustrata see Eric Cochrane, Historians and Historiography in the Italian Rennaissance (Chicago: University of Chicago Press, 1981), pp. 34-40.

16 For the rhetorical-scientific division as applied to authors of historical works, including Biondo, see Denys Hay, "Flavio Biondo and the Middle Ages," Proceedings of the British Academy 45 (1959), 99. The point is taken up again by D. R. Woolf in "Erudition and the Idea of History in Renaissance England," Renaissance Quarterly 40 (1987): 11-48, and by Joseph M. Levine, Humanism and History (Ithaca, N.Y.: Cornell University Press, 1987), pp. 73-106.

17 Sir Thomas Kendrick, British Antiquity (London: Methuen, 1950), pp. 134-67, and Richard Helgerson, "The Land Speaks: Cartography, Chorography, and Subversion in Renaissance England," in Stephen Greenblatt, ed., Representing the English Renaissance (Berkeley: University of California Press, 1988), pp. 327-61.

18 Powicke, 71, and R. J. Dunn, ed., William Camden: Remains Concerning Britain (Toronto: University of Toronto Press, 1984), xvi.

19 F. J. Levy, "The Making of Camden's Britannia," Bibliotheque D'Humanisme et Renaissance, 26 (1964): 71, and Piggott, 207-8.

20 Graham Parry, The Seventeenth Century: The Intellectual and Cultural Context of English Literature, 1603-1700 (London: Longman, 1989), p. 167. 